\title{
Managing Urban Transformations of Refugee Settlements in West Delhi from Camps to Nagars: The Story of Moti Nagar and Kirti Nagar
}

\author{
PRERANA CHATTERJEE \\ Architect and Urban Designer, New Delhi, India
}

\section{Email: ar.prerana18@gmail.com}

Received: November 1, 2014 | Revised: January 19th, 2015 | Accepted: January 20th 2015

Published online: January 21, 2015

The Author(s) 2015. This article is published with open access at www.chitkara.edu.in/publications

\begin{abstract}
Migration has become a common phenomenon in the contemporary world. In the Post World War II period, due to social and political unrest between conflicting and dividing nations, many countries across the globe saw migrations at different scales. The pressure created by the inflow and outflow of a huge population, within a comparatively short span of time, created various urban dynamics that have been reflected in the urban fabric of cities through largescale creation of camps, refugee colonies, workers' and migrants' colonies, urban villages and slums, many of which have survived due to good governance or political and urban development management systems. On the other hand, several others have fallen prey to various social distresses and suffered as underdeveloped or undeveloped archaic areas causing hindrance to development and prosperity of adjacent urban areas.

The socio-economic condition that developed in New Delhi after the Partition in 1947 saw migration of millions overnight, with the creation of a large number of refugee camps in the city. This paper describes the courageous survival of one of these camps at Basai Darapur as well as the ambitious transformation of such camps to the colonies Moti Nagar and Kirti Nagar, over time, with proper management, through urban governance, socio-political aid, urban planning visions and urban design guidelines. The paper also attempts to discuss the possible holistic future of Moti Nagar and Kirti Nagar in coming times through careful urban management, considering opinions of different urban local bodies, real-estate stakeholders and public participations in different phases of urban development aided by the Delhi Masterplan 2021.
\end{abstract}

Keywords: Migration; Refugee Camps; Social Integration; Urban Transformation; Urban Management; Urban Design

\section{PARTITION OF 1947: A BLESSING OR A CURSE IN THE MAKING OF MODERN INDIA?}

The Partition of 1947 which formed India and Pakistan respectively, is being remembered as one of the most 'awakening' and 'ghastly' incidents in the Indian subcontinent. Though the entire episode of the sub-continent's division, forced migration and rehabilitation has been portrayed by the majority in both the affected nations as the worst of the curses that any land and its people can

Creative Space (CS)

Vol. 2, No. 2,

January 2015

pp. 183-208

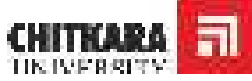

(C)2015 by Chitkara University. All Rights Reserved. ever encounter, it is also noteworthy to observe that the conditions created 
Chatterjee, P. in its aftermath, also boosted a very strong urge for growth of the nations through advancements in technical education, building of a composite culture, rapid industrialization, renewal of liberal thinking, and a much accelerated urbanization and extensive city-building. In a nutshell, Partition of 1947 in India was almost like an eye-opener for the long enslaved population, which unleashed the potential and vigour to give up its colonial shackles and rise to the ambitions of becoming one of the most significantly developing Asian nations in the future.

\subsection{Need for Effective Urban Management during the 'Emergency Years' (1947-50)}

"Refugees are [being] sent all over India. They will scatter communal hatred on a wide scale and will churn up enormous ill-will everywhere. Refugees have to be looked after, but we have to take steps to prevent the infection of hatred beyond the necessary minimum which cannot be prevented."

\section{Rajagopalachari, Governor of Bengal, September 4, 1947}

Welcomed by few, and hated by many, the aftermath of the Partition proved to be a test for 'survival of the fittest' for the refugees who migrated to India from Pakistan. With no homes, no jobs, precious property left behind, and even loss of families killed in communal hatred, there was little hope left for the masses pouring into the country. In such a situation, which posed threats like social anarchy, economic breakdown and frequent genocides, the newly formed government felt the need for an extensive urban management framework, which would, firstly, aid the newcomers in all possible ways, and secondly, provide conditions and opportunities to grow and settle so that they would gradually accept India as their new home (Guha, 2008). The World Wars, by this time, had taught some lessons on 'management criteria to be essentially formulated during such periods of crisis (Glick, Çaglar, 2009). The then Indian Government also adopted many such measures as precautions. Some of the major concerns regarding the refugees that were addressed were those of identity-crisis, lack of belongingness, economic impoverishment, poor healthcare and sanitation, and uncontrolled population growth.

As a major step of Urban Management, the Government of India, led by Prime Minister Jawaharlal Nehru, set up the Ministry of Rehabilitation on 6th September 1947 (Datta, 2002). Several other organizations, such as Refugee Rehabilitation Committees and Refugee Welfare Associations were formed 
in various major states, especially the ones which had suffered extensively, e.g., Delhi and West Bengal. The Ministry of Urban Development also marked some cities, where huge refugee infiltration was occurring in search of jobs, healthcare and safety. A number of major schemes were also announced to efficiently manage the urban development in these cities, viz. emergency refugee camps at strategic locations to organize uncontrolled squatting of refugees, new markets and shopping centres to grow more jobs for the population; educational facilities like camp colleges and polytechnics specially dedicated to the refugees; new physical infrastructure (drains, drinking water facilities, public toilets, etc.) for controlling pollution and environmental hazards and maintain sanitation standards in urban areas; hospitals, nursing homes, local clinics and dispensaries for healthcare; urban co-operative societies and relief associations to provide necessary help by providing blankets, warm clothes, fuel for cooking, etc. (Datta, 2002).

Apart from these, one of the major interventions which drastically changed the urbanscapes was the development of new towns for residences, with vast industrial areas for economic replenishment, for the refugee population. Delhi, the new capital of the country, which faced one of the maximum influxes of refugees in the country, saw an extensive building of such new neighbourhoods called 'Nagars'. These defined a whole new genre of neighbourhoods and, with their strategic urban development guidelines, became successful planning models exhibiting the practical workability of the abovesaid schemes. Development of the Nagars in Delhi not only provided the refugee population with new homes, new job prospects, new identity and sense of belongingness, but also, their introduction is considered as one of the major interventions in rebuilding Delhi.

\section{DELHI: FROM AN IMPERIAL CAPITAL TO A CITY OF 'REFUGEE NAGARS'}

Brij Krishnan Chandiwala, a noted Congressman, once wrote to Jawaharlal Nehru about the growing Punjabi population in New Delhi after the Partition, and his concern regarding these outsiders outnumbering the natives of the city: "The people of Delhi are living a life of helplessness... They have on their own wiped out their exclusive identity forever... The Delhi residents have become strangers in their own house." Nehru addressed back: "Some of the complaints you make are the unfortunate consequences of the Partition.... But Delhi has also become a cosmopolitan city with a large number of foreigners here..." Chandiwalla reacted to this statement, considering the uncertain future these foreign intermixes may call for: “... In this city everyone who resides has come from somewhere else. And over the years they became part of this city. I believe
Managing Urban

Transformations of Refugee

Settlements in

West Delhi from

Camps to Nagars:

The Story of Moti

Nagar and Kirti

Nagar 
Chatterjee, $\mathrm{P}$.

even these people (Punjabi refugees) will one day start identifying their selves as belonging to the city." (Kaur, 2007)

The birth of a hybrid New Delhi, as reflected in the above-said conversation, was indeed inevitable. Few then could believe that Delhi, once the seat of power during the Mughal Period, and the Imperial Capital of the British in India, will be the future Capital of the country, with much of its urban character represented by numerous Punjabi refugee colonies. The migrants, through their determination, had created a new social order. Beginning from scratch, through extensive management and planning aid from the government, they succeeded in developing their meagre refugee camps into 'Nagars'. Trying to fit their lifestyle into the given built environment, they developed their own homes, enterprises, and above all, their own social identity which successfully amalgamated with the Indian context to form a new urban expression, especially in parts of West Delhi. Moti Nagar and Kirti Nagar are two such Punjabi refugee settlements in West Delhi that hold the testimony of this success.

\section{REMINISCING THE PAST}

Initially it was neither easy for the Rehabilitation Authorities to settle the refugees, nor the latter to familiarize themselves to foreign conditions. Despite this and amidst the turmoil of rehabilitation, the then Minister for Rehabilitation, Mr Mohan Lal Saksena (1948-50), expressed his hope: "the energy and courage, enterprise and self-reliance of the displaced persons themselves led me to hope that it may be given to me to assist these stricken people, and uprooted millions, in their settlement; and if possible in making them the pioneers of a new social order" (Kaur, 2008).

Population Growth in Delbi Area from $190 /$ to $1971^{1}$

\begin{tabular}{|c|c|c|c|c|c|}
\hline Year & l'ersons & $\begin{array}{l}\text { Decade } \\
\text { rariation }\end{array}$ & $\begin{array}{l}\text { Pertexaldoge } \\
\text { decade } \\
\text { varianon }\end{array}$ & Male & Jemale \\
\hline $19 \pi 1$ & $4,05,819$ & - & - & $2,17,921$ & $1,87, \hat{B 9 B}$ \\
\hline 1911 & $4,13,851$ & $+B, 032$ & 1.98 & $2,32,865$ & 1,82,986 \\
\hline 1921 & $4.8 \mathrm{H} .452$ & $+74,601$ & +16.53 & $2,81,777$ & $2,26,675$ \\
\hline 1931 & $6,36,244_{1}$ & $+1,47,744$ & +30.26 & $3,64,447$ & $2,66,744$ \\
\hline 1941 & $4,17,939$ & $+2,81,693$ & $+44,50$ & $5,35,236$ & $3,62,203$ \\
\hline 1951 & $17,44,072$ & $+8,26,1,13$ & +90.00 & $9,86,558$ & $7,57,534$ \\
\hline 1961 & $26,56,612$ & $+9,1+, 540$ & +52.14 & $14,89,378$ & $11,69,234$ \\
\hline 1971 & $40,65,698$ & $+14,07,086$ & +52.92 & $22,57,515$ & $18,06,187$ \\
\hline
\end{tabular}

Table 1: Population Growth in Delhi Area from 1901 to 1971. (Census of India 1961-1971) 


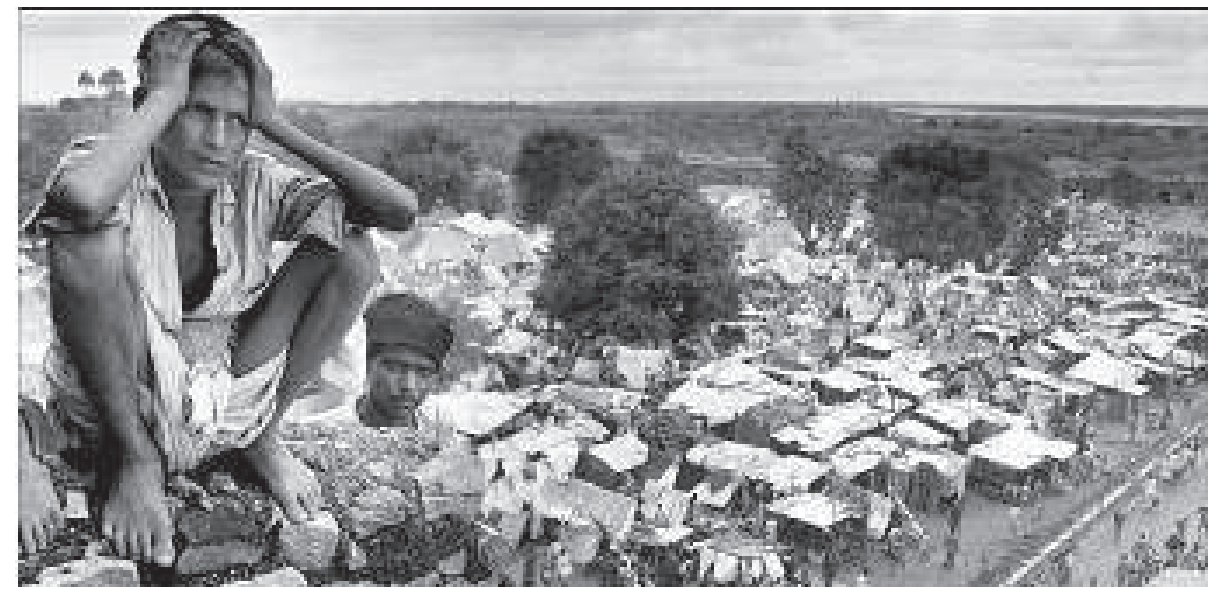

Managing Urban

Transformations of Refugee

Settlements in

West Delhi from

Camps to Nagars:

The Story of Moti

Nagar and Kirti

Nagar

Figure 1: Visual of a Refugee Camp in Delhi (Image Source: The Partition Archive 1947. Website: www.1947PartitionArchive.org)

Of the 47.5 lakhs of people who migrated to India, 495,391 came to Delhi itself (Table 1). Of the total urban population of Delhi at that time $(1,437,134)$, about 32.7 percent constituted of refugees (Datta, 2002). It was a huge challenge for the existing infrastructure of the city to house and control such a huge newly arrived mass through urban planning and design. The birth and transformation of these mere squatters to successful neighbourhoods can be enumerated in three phases which devised different schemes during three consecutive periods of time and are almost reflected as three different layers, one above the other, forming the resultant urbanscape of today's West Delhi. The three phases are:

1. Before the Master Plan (1947-1955),

2. Emergence of the First Master Plan MPD 1962: (1955-1981), and,

3. After the Master Plan (1981-2011), with new issues questioning old principles

\section{BEFORE THE MASTER PLAN (1947-1955)}

The newly arrived population, being directionless, squatted wherever possible, clogging every corner of the city. Other than occupying gurudwaras, dharamshalas, military barracks, gardens and abandoned tenements of Muslims who had migrated to Pakistan, they thronged in camps and slums (Fig. 1) which sprouted along railway platforms, streets, pavements. Some of the notable locations include areas around Jama Masjid, Purana Qila, Humayun's tomb, Shahdara, Subzi Mandi, Paharganj and Sadr Bazar (Lahiri, 2011) (Fig.2). 
Chatterjee, P.

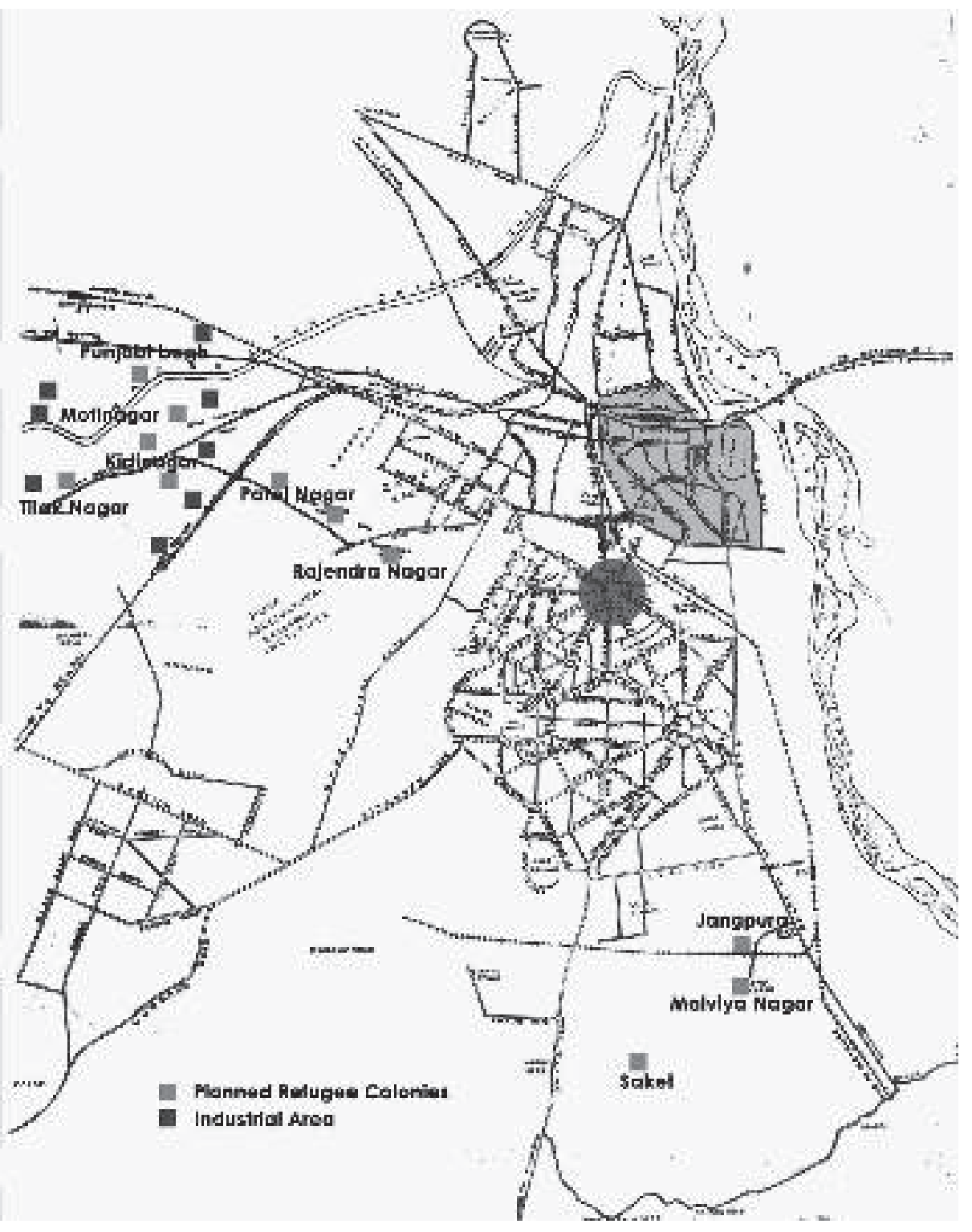

Figure 2: Locations of the Planned Refugee Colonies and newly developed Industrial Areas in New Delhi (Image source: Author). 


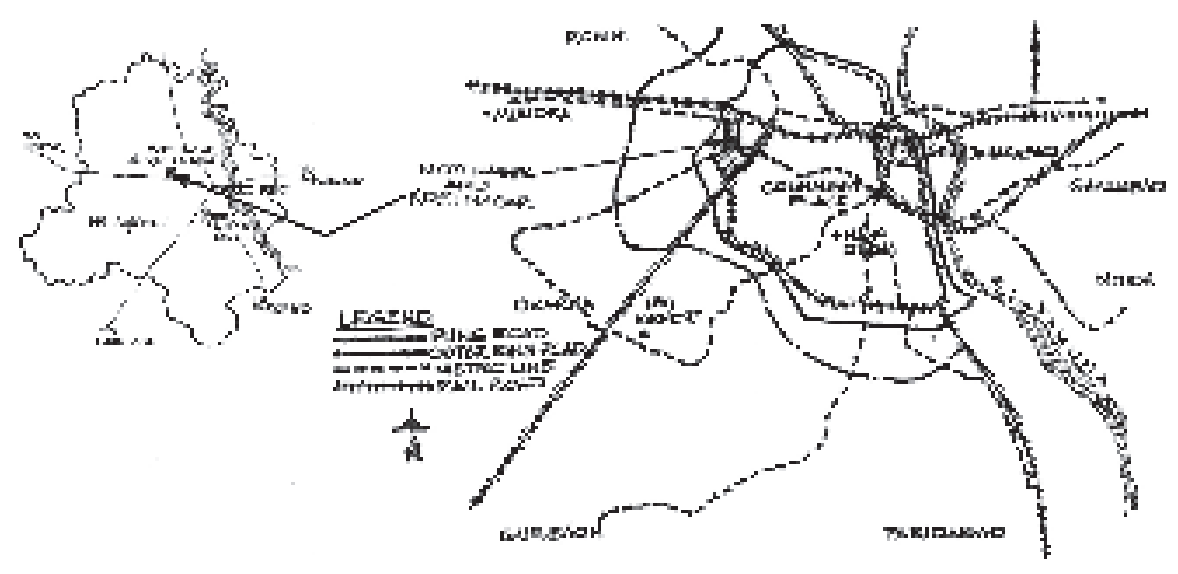

Managing Urban

Transformations of Refugee

Settlements in

West Delhi from

Camps to Nagars:

The Story of Moti

Nagar and Kirti

Nagar

Figure 3: Location of Moti Nagar and Kirti Nagar on the Map of Delhi (Image source: Author).

The only hope provided to them all was a small ritual conducted on their arrival - the issue of a 'refugee card' with name, registration number and date of arrival, which ensured them a ration card, temporary housing, education and employment opportunities reserved for the migrants (Kaur, 2008). These rights were distributed on the basis of their belongings in Pakistan, number of family members and their ability to pay for the new property. Aiding bodies like 'Delhi Improvement Trust' and 'Refugee Protection Society' conducted these allotments.

This was when one of the biggest moves was taken in the history of urban development in Delhi -- the newly formed government proposed as many as 36 Rehabilitation Colonies for refugees as 'Emergency Projects.' These were mostly named after famous Indian leaders, e.g., Rajendra Nagar (after Rajendra Prasad), Lajpat Nagar (after Lala Lajpat Rai), Moti Nagar (after Motilal Nehru), etc. (Guha, 2009). As the city centre was already developed, these new colonies were mostly located in West Delhi on the other side of the Central and South-central ridges where vacant land (old Rajput villages) were available.

Moti Nagar was formed in 1948-50, aided by the Delhi Improvement Trust, to accommodate the people living as temporary squatters at Jhandewalan, Shadipur and Basai Darapur, which used to be Rajput villages with humble hutments and vast expanses of farmlands bordered by dense forests (Fig. 3). After the partition, these lands came under government ownership and were put together into small parcels to be developed for the refugee colonies. Moti 
Chatterjee, P.

Nagar was formed from a part of Basai Darapur, with Shivaji Marg and Patel Road as its boundaries as well as major connections on the east and north, the Sahibi River (which later became Najafgarh Nallah, an open sewer line for collection of wastewater from most of the newly formed colonies in West Delhi) as its edge on the west and, the Moti Nagar Nallah to the south. With the first squatter refugee settlement in Basai Darapur, a small daily market street came into being, leading from the camps to a Gurudwara, a Sikh Temple, which was established by the residents themselves. This street became a commonly availed one and the market strengthened this spine. Moti Nagar was constructed almost at one go with this bazaar-street becoming the Moti Nagar Market as the structural backbone of the settlement. The market had shops, workshops and small-scale industries as small enterprises run by the residents in and around the area to support their families. In order that the public and private activities within the neighbourhood work in tandem with each other, the 'Live-Work-Leisure' relationship was given primary importance while designing the urban form (Fig. 4, 5, 6).

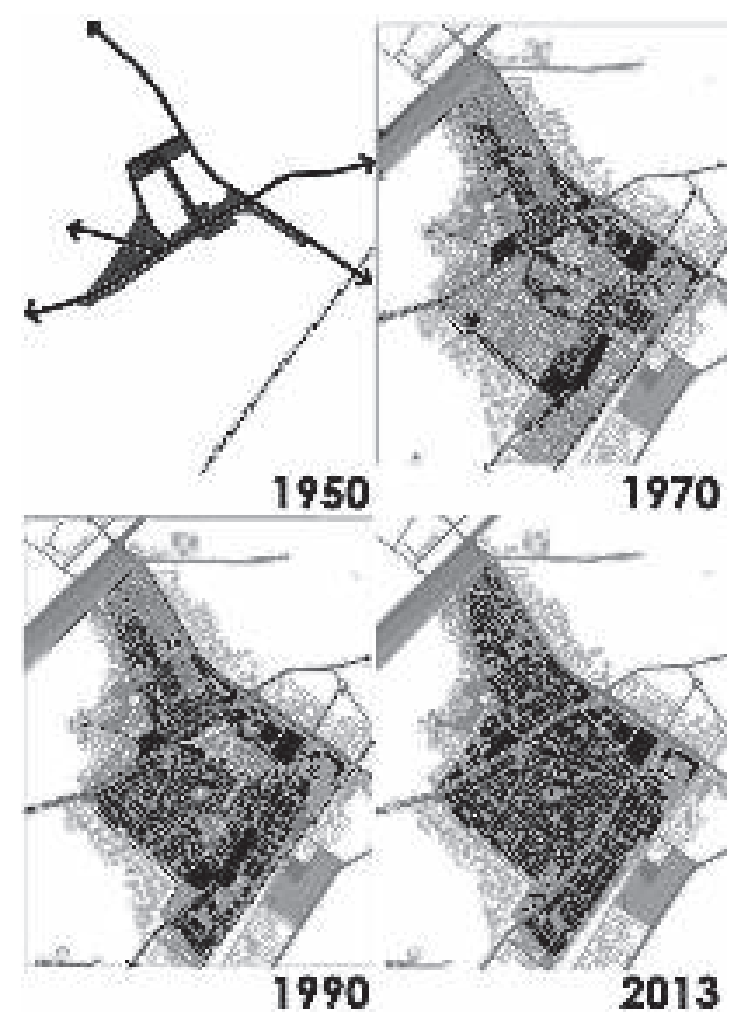

Figure 4: Evolution of Moti Nagar \& Kirti Nagar (Image source: Author). 

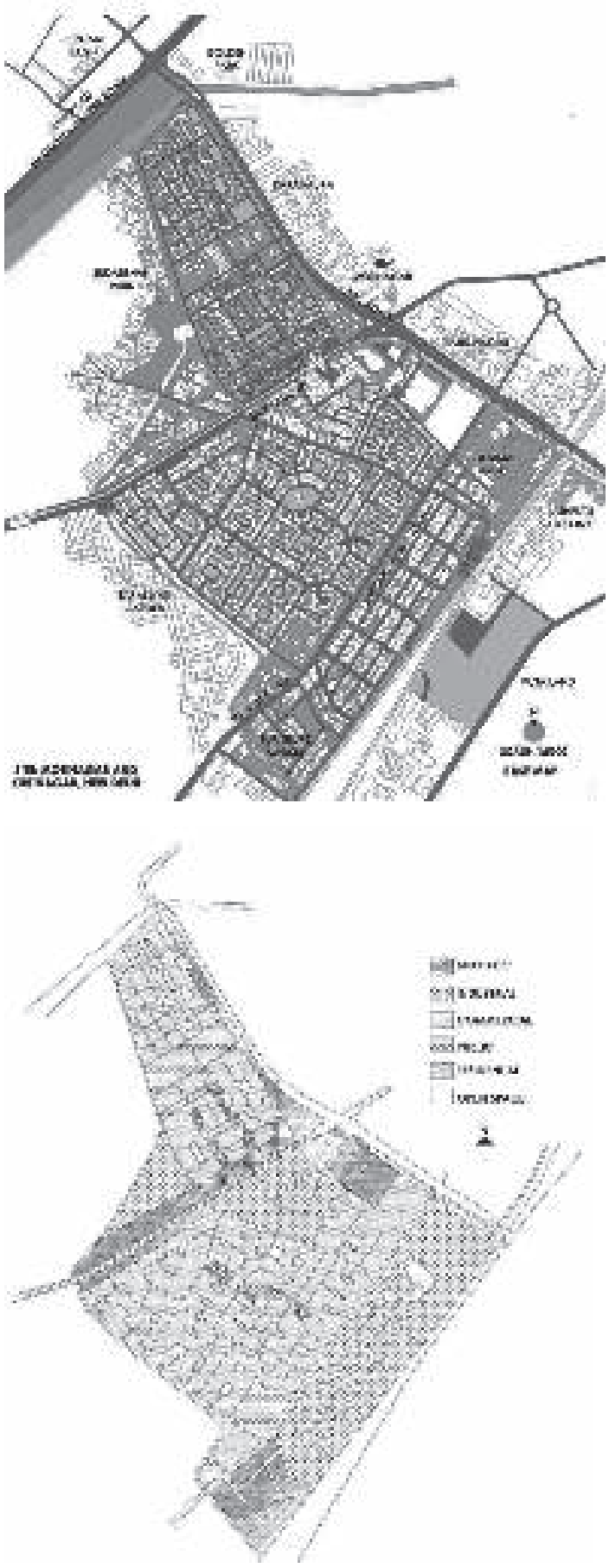

Figure 5: Plan of Moti Nagar and Kirti Nagar (Present Day) (Image source: Author).
Managing Urban Transformations of Refugee Settlements in West Delhi from Camps to Nagars: The Story of Moti Nagar and Kirti Nagar
Figure 6: Land Use Map of Moti Nagar and Kirti Nagar (Image source: Author). 
Chatterjee, P.

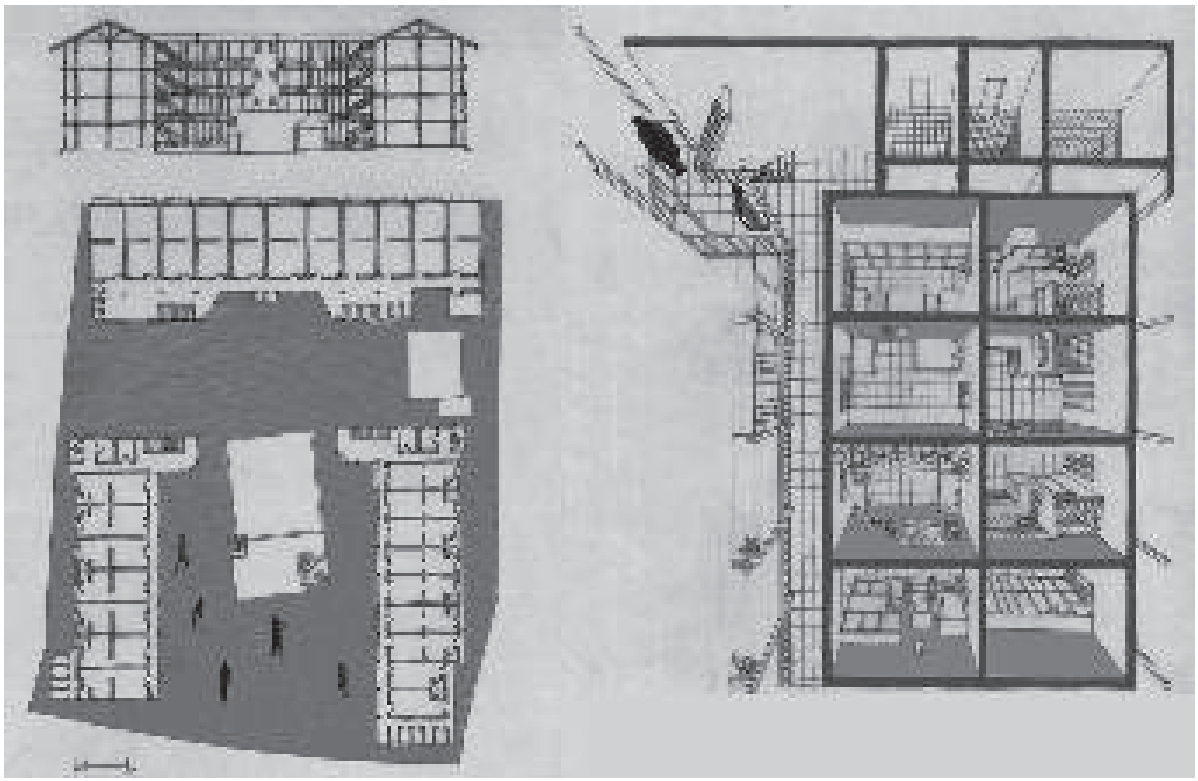

Figure 7: Design of Chawls in Girigaon Mumbai (Source: Karandikar, P.N., 2010).

The 'chawl-type' of housing ${ }^{1}$ (Fig 7), commonly found in Mumbai, was found to be a desirable solution to this problem by the architects of Sir J. J. School of Planning in Bombay (now Mumbai) who designed the typology of housing for Moti Nagar. The 'Chawl' had proved be a very successful typology for accommodating migrants in Mumbai who poured into the city from the suburbs after the booming of the cotton industry in the 1860s. In the 1950s, when a similar situation occurred in Delhi, the 'Chawl' was the considered the only suitable option for housing the refugees. Each cluster was designed as a two-storeyed square with a row of 8 rooms (10'x 20' each) on each side, lined by shops at the outer edge and common toilets at the four corners. Towards the inside, the rooms overlooked a courtyard at the centre of the cluster, which was accessed from outside through entrances at the centre of each side (Karandikar, 2010) (Fig. 8).

The courtyard became the central interactive space for all the families living in the cluster. In fact, the courtyard became the smallest unit in the hierarchy of community spaces in the neighbourhood. According to Neera Adarkar, architect and urban researcher, the overcrowded chawl became the 'quintessential icon

\footnotetext{
${ }^{1}$ A housing cluster containing a courtyard with an array of rooms all around overlooking it, which was devised to contain a huge number of families at minimum expense
} 
HOUSING TYPOLOGY

\section{TRANSFORMATION OF BUILT FORM}
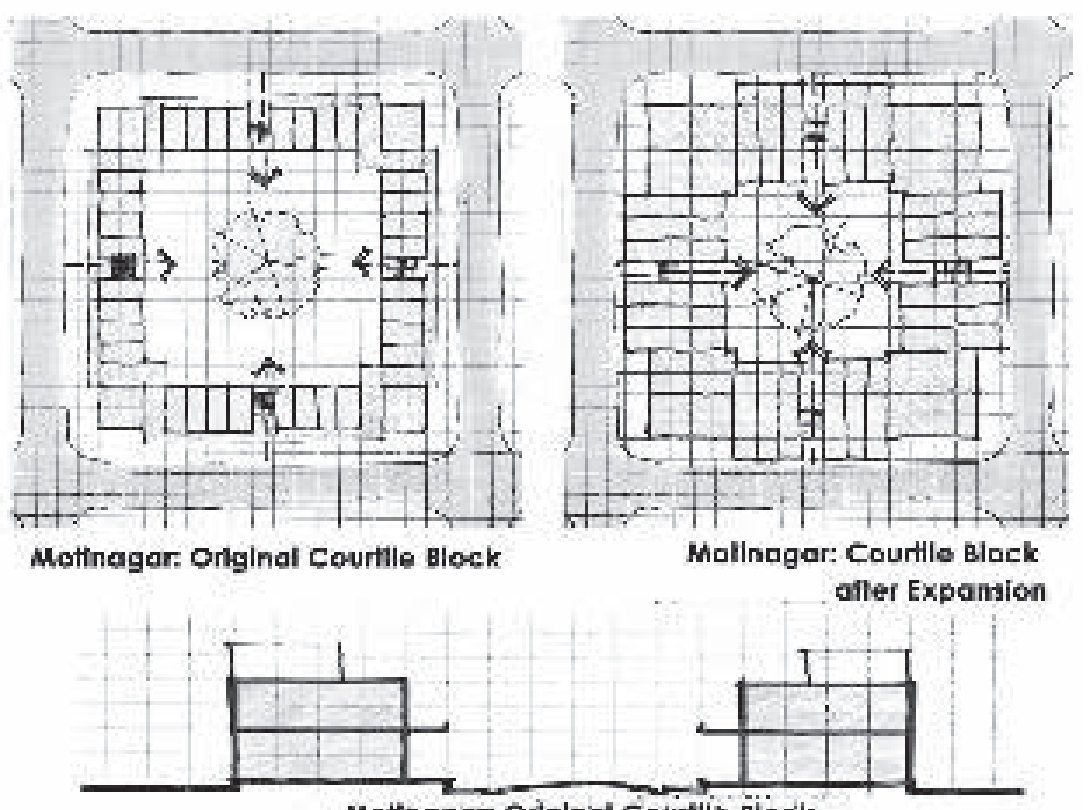

Motlnagar: Origlnal Courtlis Biack

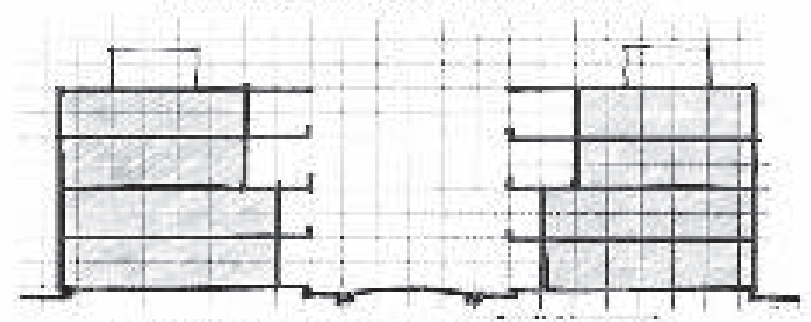

Motinagar: Courtile Black after Expansian

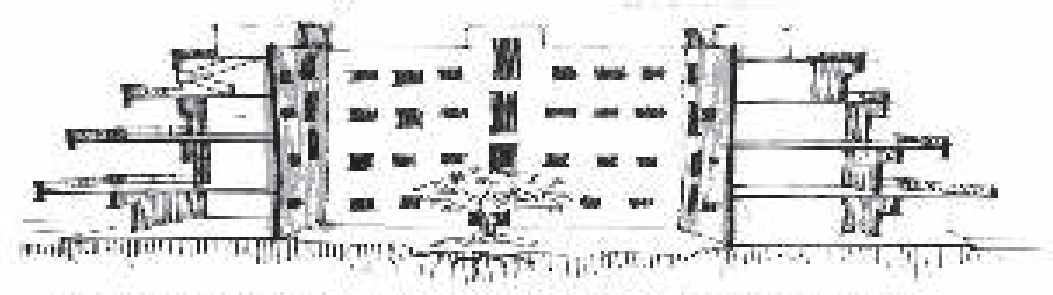

Moll Nagar: Section showing receding floors as we go higher

Figure 8: Transformation of Chawl-type housing of Moti Nagar showing expansion and intrusions in plans and sections (Image source: Author)
Managing Urban

Transformations

of Refugee

Settlements in

West Delhi from

Camps to Nagars:

The Story of Moti

Nagar and Kirti

Nagar 
Chatterjee, $\mathrm{P}$.

Figure 9: Elevation Sketch of Moti Nagar Market (Image source: Author)

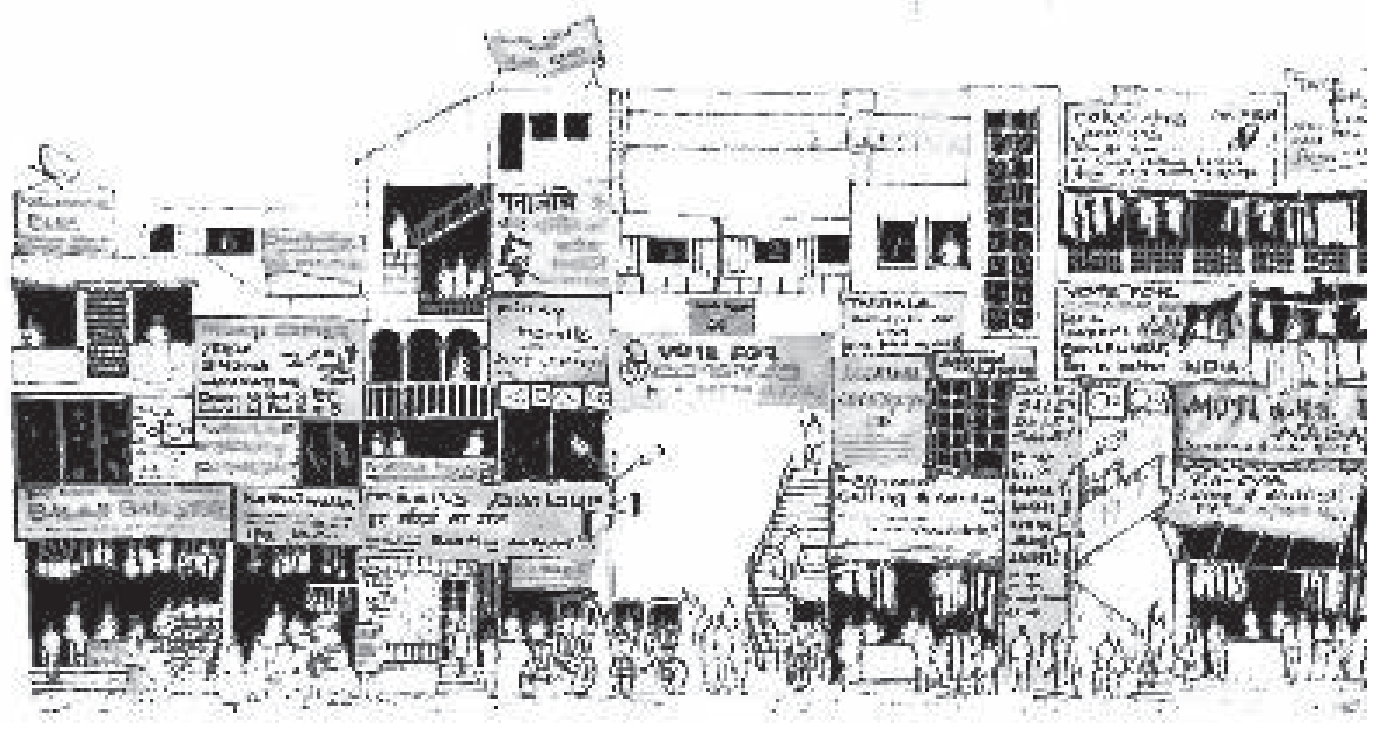

of the working class dwelling' and 'were transformed by their inhabitants into active political, social and cultural spaces' (Adarkar, 2012). A similar typology was chosen in Moti Nagar also, aiming to strengthen the social bonds among communities within the refugee settlement which were subjected to extreme social repulsion by the native Delhi population. Such an urban pattern also formed a strong relationship between various activities, as the residents worked in the shops in front and relaxed in the courtyard at the back, clearly defining the public and private edges of the clusters. Together the outer edges of the clusters lined by shops and workshops, formed busy markets and safe streets. They provided work opportunities as well as common goods required by the neighbourhoods in daily life, selling home-made products like pickles, kites, pottery, wooden toys, jewellery and other handicrafts, which were mostly made by women in the courtyards of the houses.

Altogether, a typical, sustainable 'Live-Work-Leisure' relationship was encouraged by such an urban form: people inhabiting these used to work in nearby shops and did not have to travel far for jobs (Fig 9). Being the heart for social-interaction, the marketplaces became the most important public spaces in the neighbourhoods, and, in the evening on their 


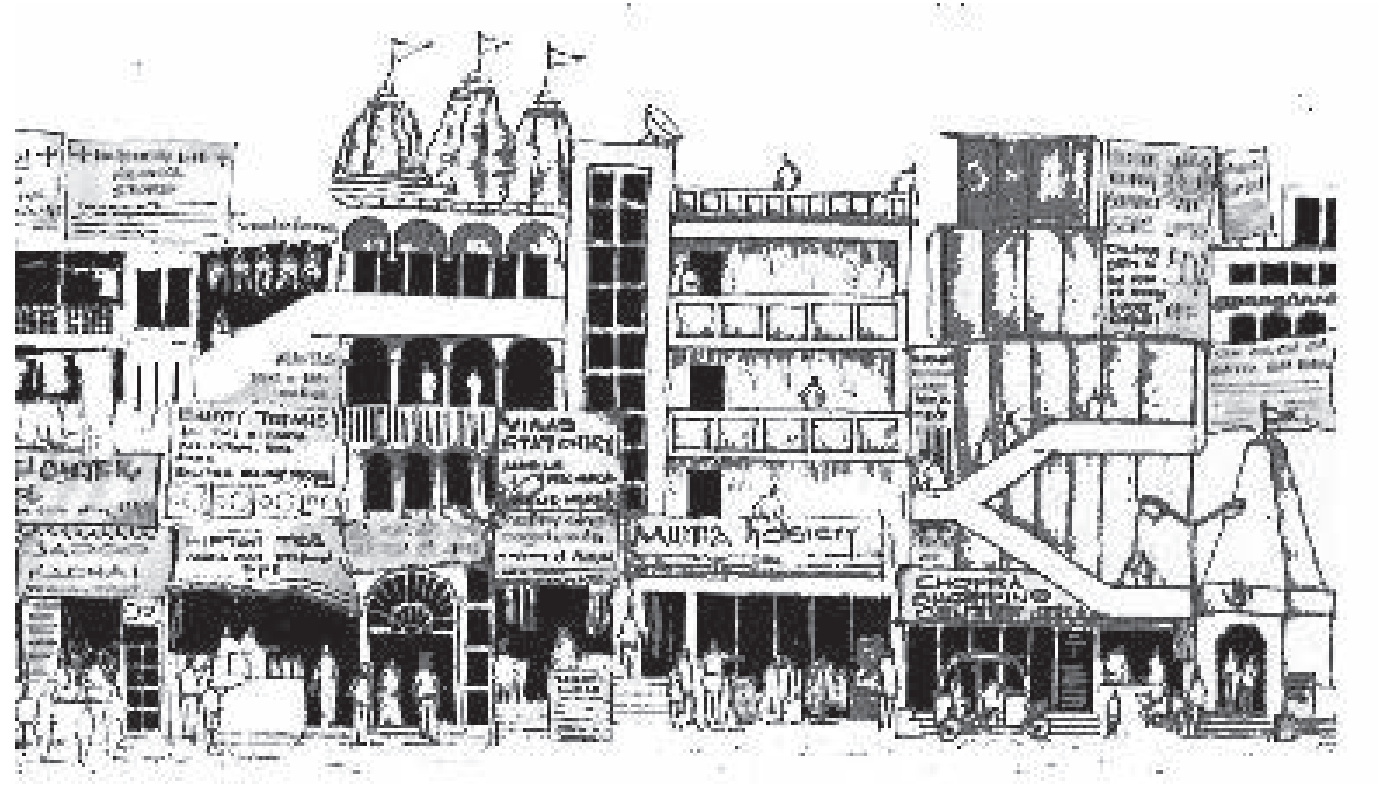

Managing Urban

Transformations of Refugee

Settlements in

West Delhi from

Camps to Nagars:

The Story of Moti

Nagar and Kirti

Nagar

way from the Gurudwara, residents would gather in shops to have refreshments and socialize with neighbours. During festivals like Gurupurab (Guru Nanak's Birthday) and Independence Day, these streets became stages for festivals and ceremonial processions. People gathered in and around the Gurudwara for 'chowkis' and 'langars', while sweets and colourful clothes were sold in shops for the happy occasion; vibrant shades of kites painted the skies that celebrated the much treasured freedom and joy of thousands.

Although such a remarkable effort in urban planning and management provided the refugees with a new habitat promised with security, hospitality and economic prospects, still the pressure of the growing population was profuse and out of control and hindered the rehabilitation procedure. Illegal extensions and additions led to disorganization of the urban pattern, affecting the city as a whole. Besides, the refugees and their neighbourhoods, being thoroughly ignored by the original natives of Delhi, were becoming non-communicative nuclei around the main city which lacked urban coherence. The situation urgently required a strong planning and implementation philosophy that would respond holistically with the comprehensive urban design scheme for Greater Delhi as a whole. 

1981)

Since, all the developments were occurring in bits and pieces without any co-ordination, the holistic development of the city was being neglected. Moreover, the organizations looking after these developments were thrown into competition amongst themselves, some even making money through the distribution of properties which were collectively endangering the 'fair face' of Delhi (Lahiri, 2011). To combat such a situation an overall planning scheme that would collectively address the civic, socio-economic development issues was decided to be taken up. A long range plan (10-15 years) was needed to guide this scheme sequentially, for which Nehru, in 1955, urged the formulation of a government propelled Master Plan (Lahiri, 2011). On 30 ${ }^{\text {th }}$ December, 1957, the Delhi Development Authority (DDA) was formed to guide development of Delhi till 1981 according to the Master Plan of Delhi, 1962. The MPD 1962 was certified by the Delhi Development Act (1957).

The vision of this plan, as regards the design of the refugee settlements, was to manage incongruous population-growth and control quality of infrastructure development. Some of the objectives were:

1. To control population distribution in the city, through decentralization of the city-core.

2. To check congestion in rehabilitation colonies through design guidelines with fixed densities and carrying capacities facilitated through provision of an extra floor to the blocks in some cases.

3. To have hierarchies in a community as in residential and commercial developments.

4. To promote self-sustenance of communities by allocating industries and markets in each.

The guidelines solved the rehabilitation problems partially, but shaped the 'Nagars' into urban forms somewhat like British Industrial Towns. Often, the Industries were at one end, located with respect to wind directions, calling workers with hoots of siren from the concentric residential areas which resembled the barracks of workers' colony in Manchester. The blocks had service lanes or courtyards for private circulation, and backyards for locating the drains. Such an inspiration was drawn by the planners and architects, keeping in mind the lifestyle and behaviour of the working class which was a condition created by the socio-economic context of the Indian Capital city after Partition, and, like the western industrial towns, bore the scar of a divided society, social groupism and economic inequalities. The layouts of the British 

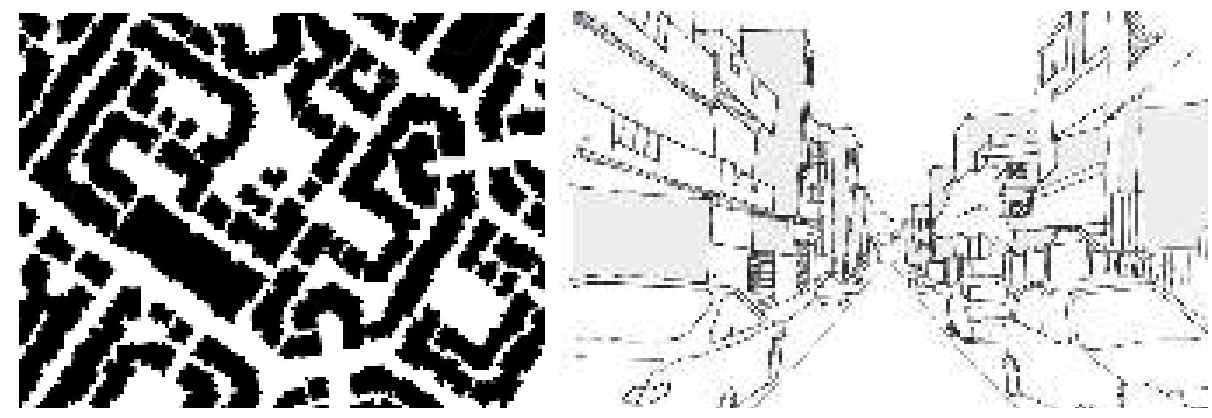

Managing Urban

Transformations of Refugee

Settlements in

West Delhi from

Camps to Nagars:

The Story of Moti

Nagar and Kirti

Nagar

Figure 10a (Left above): Figure-ground pattern of Kirti Nagar Residential Area

Figure 10b (Right above): Urban Form of Moti Nagar (Image source: Author)

Industrial Towns, Garden Cities (New Industrial Towns), and the Post World War II New Towns principally aimed at serving the working class where socioeconomic conditions played a pivotal role in planning urban areas and pushed behind spatial and geometric factors to lesser importance, as far as the physical design principles were concerned. The social differences were combated by an attempt to create strong social ties amongst the residents with elements like active public places (e.g., markets) and interactive public and private open spaces (e.g., parks and courtyards respectively).

Kirti Nagar, formed by DDA as a plotted housing development with industries for the refugees, is based on a very similar model. It shows a very distinct open space network in its design layout, which follows a hierarchy from private cluster-level open spaces to public parks. The clusters were designed in C-shaped and L-shaped loops, with semi-attached houses surrounding small fenced open spaces with gardens where people of all age groups gather (Fig. 10a, 10b). People can enjoy morning and evening walks along the calm and quite walkways through the gardens, while the old can recline and rest on seats under the shades of trees. Children also enjoy playing in tot-lots in these gardens while under supervision of their parents who, residing in the surrounding houses, can keep an eye on the kids from the balconies. In addition, there are parks surrounded by a number of such clusters that form the next higher level in this hierarchy. These are found besides the primary and secondary schools and, though small, they form playgrounds for school children. At the centre of the neighbourhood is an open space with a small building serving as a community centre. Though scarce, these open spaces are connected by a network of streets, structuring the neighbourhood by forming breathing spaces amidst the built masses. 
The residential zone was divided from the industries by a major arterial road, the two sides of which respectively accommodate household retail and industrial retail activities. The Industries are mostly large scale ones like furniture, timber, cereal, auto parts manufacturing, etc. The Kirti Nagar Railway Station helps in loading-unloading of raw materials coming from the hinterlands in the peri-urban areas. The other industrial area was to the west of the neighbourhood which were mainly a conglomeration of small scale un-polluting industries aimed at repair and packaging. The residences, industries and open spaces in Kirti Nagar also fostered a 'Live-Work-Leisure' relationship, but very different from that of Moti Nagar. This one was more formal with the urban form aimed at segregating the activities rather than amalgamating them as seen in the former case.

The utmost success in the planning and design of Moti Nagar and Kirti Nagar was that a simple set of urban development guidelines was successfully translated into a physical urban form with effective incorporation of essential factors like security, communal harmony, social upgradation through education and job allocation, all being done at the face of a national emergency situation along with a tremendous growth of population. But, alongside its success story, the Master Plan also suffered some drawbacks. The designed self-sufficient neighbourhoods spontaneously became self-centred without any connections with the surrounding settlements. Besides, the majority of the outgoing migrants from Delhi to Pakistan were traders and craftsmen while those who came in were farmers. Hence, the latter had to work very hard to acquire industrial skills. Many opened workshops and repair shops on the ground floor of their houses. In Moti Nagar, the extra floors (second and third floors) allowed by the new plan, were rented out to raise money, leading to even more congestion. Illegal settlements and unauthorized local markets sprouted along main roads, eroding much of the character of the urban form. Moreover, prosperity, successful entrepreneurship and education amidst the residents of this neighbourhood also brought about a substantial gain in social respect. They are no longer the hapless, penny-less refugees who had arrived in these lands 50 years back. Over the time, they have nurtured ambitious growth and success stories, which now needs to be addressed at the scale of the city and beyond.

\section{AFTER THE MASTER PLAN (1981-2011): NEW ISSUES QUESTIONING OLD PRINCIPLES}

The Master Plan of 1962 partly healed the wounds of Partition but also created unanticipated problems, affecting altogether the larger vision of the communities. The previous vision was thereby improved to achieve unity in 
diversity through a balanced distribution of population and wealth as well as unifying uses and harmonious intermixing of communities. The strategies were:

1. Overlapping of different land-uses to create a mixed use.

2. Promoting institutions which have replaced the industries of the past.

3. Stressing on 'Work-Home' relationship in designing communities.

4. Encouraging Public Transportation and Transit Oriented Development.

5. A revision of FARs to match the changed value of land and property along transit corridors.

With the economic upgradation of the neighbourhoods in due course of time, the very lifestyle of the communities also underwent a drastic change. Today Moti Nagar and Kirti Nagar primarily serve as residential neighbourhoods for the upper middle class citizens residing in the middle part of West Delhi. With the Master Plan 2021 encouraging Transit Oriented Development, Public Transportation was strengthened to a great extent, making travelling very easy. Road and rail corridors provide excellent connection both with the city-centre and city-outskirts. The recent arrival of MRTS has reduced time of travel between home and workplace, thereby enabling people to travel for work far away from their homes.

This has greatly affected the previous notion of the 'Live-WorkLeisure' relationship, which was the central idea behind the design of the neighbourhoods. The workspace and residential spaces are no longer needed to be in close proximity to each other, as a result of which the small repair shops and workshops have vanished, industries have become obsolete and in its place economic escalation has brought in upmarket commerce like car showrooms, brand outlets, etc. Such transformation has mainly occurred where value of land is very high and has been hit by a huge pressure of commercial development such as the edge along the Delhi Metro corridor, especially around Metro stations, as found around Moti Nagar Metro Station located in between Moti Nagar and Kirti Nagar. In order to replenish the increased value of land and property along Shivaji Road, high-end commercials, multiplexes and malls are appearing in this stretch, taking away much of the subtlety from the humble resettlement colonies. The new 'Mall Culture' has become alluring more than the old informal markets. Besides with the Master Plan 2021 encouraging mixed use, a new building type, with shopping centre in first and second floors and residences in floors above, has become popular in the present scenario. Due to a sharp rise in commerce, such development is occurring haphazardly which is challenging the physical design of the existing urban tissue.
Managing Urban

Transformations of Refugee

Settlements in

West Delhi from

Camps to Nagars:

The Story of Moti Nagar and Kirti Nagar

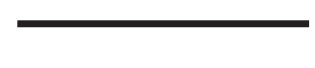


Chatterjee, $\mathrm{P}$.

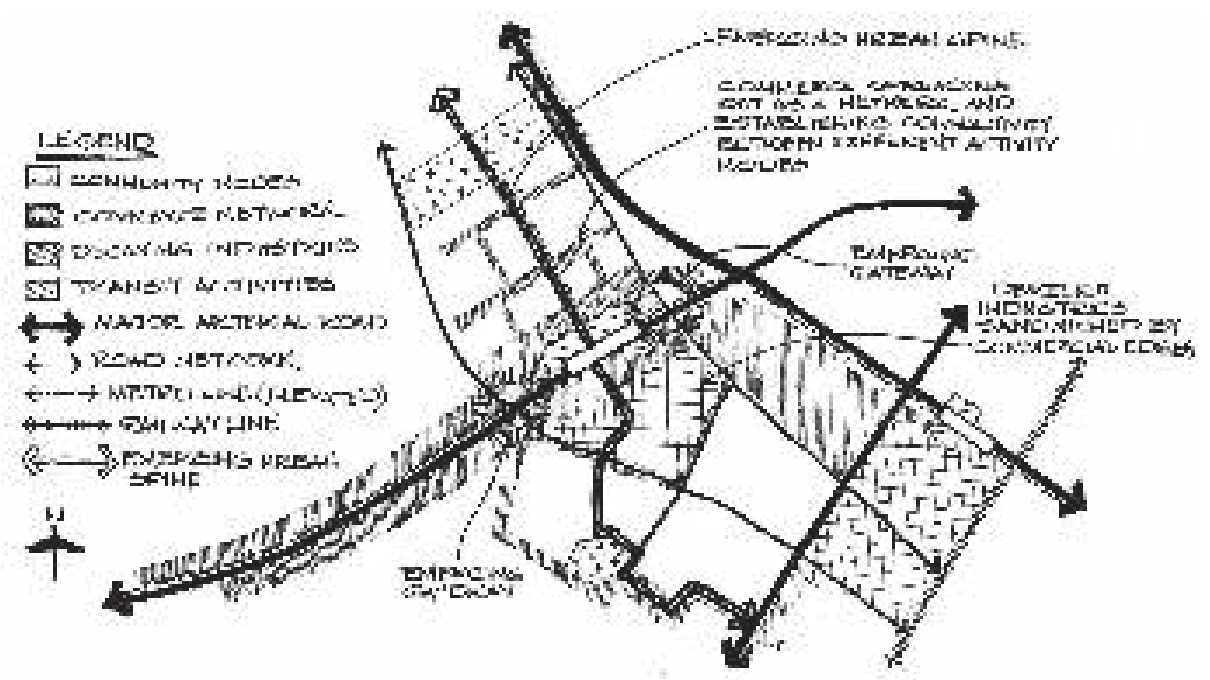

Figure 11: Urban Transformation of the Old Industrial Area along the Metro Corridor (Source: Author)

The rising economic affordability of the present generation residing in this area now demands 'Live' and 'Leisure' in economically higher dimensions. The housing units of the chawls considered fit for refugees of five decades back, no more suit the present conditions, because their descendants are now wellestablished citizens with various job-prospects, well able to afford better homes. The humble courtyards and parks are, today, too small to cater necessities of recreation amenities for people who desire clubs, banquets, game-parlours and huge playgrounds. The small businesses which meagrely supported families before have now been converted into million dollar enterprises controlling economic dynamics in Delhi and beyond -- companies like Atlas Cycles, Bhatia Opticians, and Bharat Steel Tubes were born in these colonies (Kapadia, 2006).

The bigger dreams and changing needs of these colonies are currently not satisfied by the old infrastructure of the Post Partition context. The transformations of these neighbourhoods over period have created larger issues which have their roots at the community level. Master Plan 2021 has helped in providing an overall vision and management strategies to achieve a long term goal; but in order to realise them, a set of comprehensive urban design guidelines are required which would communicate and connect the Zonal Level Issues to those of the Local Level and, thereb,y help in controlling the urban form even while fulfilling people's new aspirations as well as protecting the legacy of the past (Fig. 11). 


\section{MANAGING URBAN TRANSFORMATION THROUGH URBAN DESIGN PHILOSOPHIES}

The incongruous urban character seen in the neighbourhoods of Moti Nagar and Kirti Nagar, today, are owing to two factors: the pressure of new developments created due to the new demands of urban infrastructure by the present generation of user groups on one hand and, on the other, the boldness of the historical importance created by the past legacy of the settlements. The abovesaid two factors are pushing the urban form into jeopardy. On one hand the former attempts to create a new layer of development, while on the other hand, the latter tends to retain the old layer inundated with memories of a great struggle of the past. Such a situation can be best resolved if the two factors, instead of conflicting each other, are guided to compliment and co-operate with each other. In that case, the ideal vision for addressing the issues holistically should be aimed at "Development for Fulfilment of the Future Aspirations through Strengthening the Roots of the Past."

The 'Future Aspirations' mentioned in the vision would ideally address the needs and ambitions of the dominant youth population and should be reflected in the urban form by the new Institutions, Public Spaces, Commercial Centres and Plazas, Recreational Centres, Community Centres and Mixed Commercial and Residential Blocks, while the 'Roots of the Past' would be kept alive, side by side and harmoniously, in the urbanscape by the Old Market Spine leading to the Gurudwara as well as retrofitting new uses like institutions, commercial showrooms and youth centres in the old abandoned Industrial Sheds that provided economic sustenance to the colonies during the tough times gone by. The bold framework created by the existing open space network, the market spine and the Gurudwara is still very active and contains the soul of the two settlements. It has the potential to be the base structure for the new amenities to fit in and strengthen it to become the principal skeleton holding the newly derived urban tissue. The areas where incompatible development has occurred need to be redeveloped in response to the adjacent contexts, so that the newly designed areas can be stitched to the existing fabric. The restructured spine along with the new amenities and infrastructure would then revitalize the urban form as well as life in the settlements (Figs. 12a, 12b).

\section{URBAN DESIGN GUIDELINES}

The urban design vision, along with the philosophies so derived, are needed to be delivered through effective project management, whereas guidelines are required to be formulated responding to the present and possible future needs. Today, alongside the Delhi Development Authority and Municipal Corporation
Managing Urban

Transformations of Refugee

Settlements in

West Delhi from

Camps to Nagars:

The Story of Moti

Nagar and Kirti

Nagar

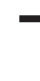




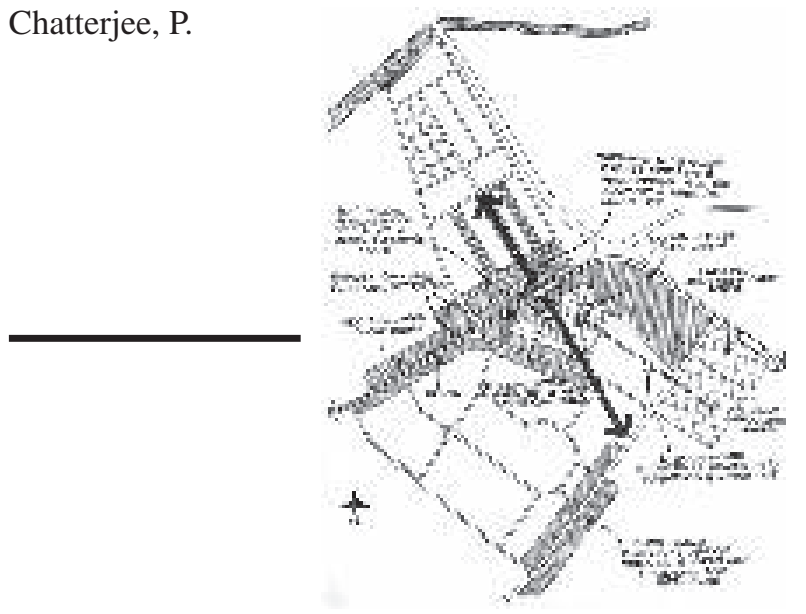

Figure12a (Above): Zone of Intervention

Figure 12b (Right): Potential area of development (Source: Author)

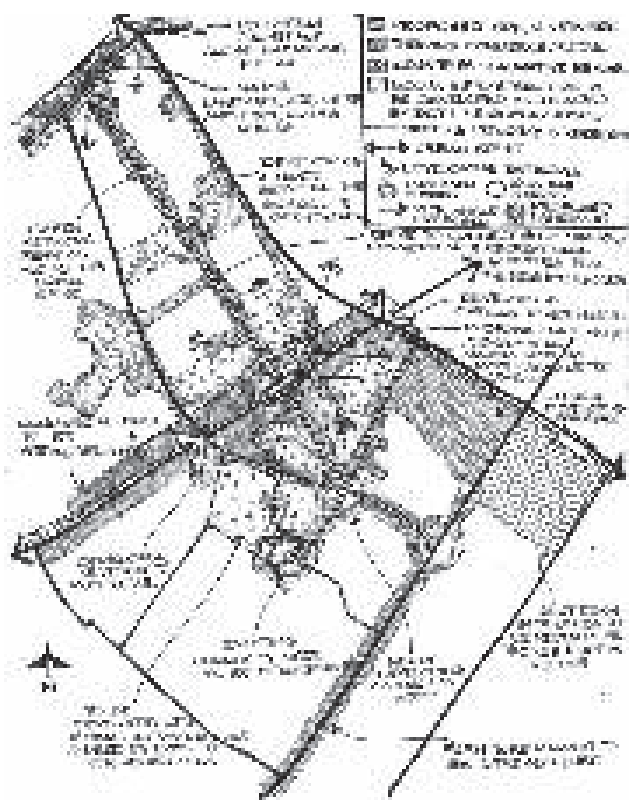

of Delhi, organizations like Delhi Urban Arts Commission, institutions like School of Planning and Architecture and many other Non-Government Organizations are carrying out extensive research work and public surveys to bring a mutual understanding between the government initiatives and people's demands. The Urban Design and Planning Departments of School of Planning and Architecture of New Delhi, in particular, have carried out Local Area Planning (LAP) and on-site Public meetings in Moti Nagar and Kirti Nagar, to propagate the various methods of urban planning and design amongst the local residents, making them aware about government initiatives and management principles in urban development procedures so that a holistic urban design can be formulated through a joint effort by the government, the urban local bodies and the various urban developers working in these wards. The urban design scheme, as developed through regular discussions and meetings, is to be communicated in the form of a comprehensive set of design guidelines. These guidelines, for an efficient execution on real grounds, should be planned into different phases, through proper co-operation with Public and Private Development Agencies.

The procedure of development in such a scenario should ideally, in the first phase, concentrate on restructuring and strengthening the existing spine which can be done by identifying the major activity centres along it and making them prominent by creation of significant public spaces. The layer of open space 
network is to be seen as a response to this active spine, and to compliment it. Diversity should be brought in both spatial and social dimensions - new open spaces are to be created in the re-designed tissues, which are to be stitched to the existing open space network to realise a holistic open space system.

The second phase should look forward to strengthening the social identity of the urban spine and the new spaces created along it. New amenities (e.g., banquets, clubs, games' centre and multipurpose halls) should be planned along the spine, which on one hand would satisfy the present and future demands of the user groups as well as contribute to the urban imageability of the neighbourhoods by adding a diversity of new activities to the character zones. To accommodate the new amenities, new building types are to be worked out which would preferably utilize the provision of Mixed Use Development (Commercial and Residential or Commercial and Institutional or Institutional and Residential, below and above respectively), stated in MPD 2021. The composite assembly of these built forms would give the resultant urban form of the new tissue that is to be merged to the high-density and low rise character of the urban fabric of the existing tissue.

The third phase would look at revitalization of the abandoned unused industrial sheds along the main spine through retrofitting of new uses like exhibition galleries, vocational training centres and small household industries (making pottery, pickle, handicrafts, toys and kites) which would showcase and encourage the rare skills the refugee colonies have always possessed and been proud of since their days of migration from West Punjab. This would not only help preserve the old tradition of the communities, but help the old activities blend with the new ones to give the resultant hybrid socio-economic image in the urban character.

The final phase would look at replenishment of the escalated land value and the high F.A.R along the public transit corridors and the main spine where pressure of development and commercial demand will be really high in the near future. This would be made feasible by revising the building types with upmarket commerce in the first two to three floors from the ground and either residences or offices accommodating private consultancies above, depending on the demands of the user groups. Such development will be possible by either replacement of singular chawl-blocks or amalgamating a number of such blocks to be redeveloped as one. The commercial centres on the lower floors would be either overlooking the public market-streets or the major spine, or even be organized around a central commercial plaza likely to fit around the Moti Nagar Metro Station. This public plaza would not only serve the two adjacent Nagars, but also act as a connector between the two making them twin neighbourhoods (Figs. 13a, 13b).
Managing Urban

Transformations of Refugee

Settlements in

West Delhi from Camps to Nagars: The Story of Moti Nagar and Kirti Nagar

$\longrightarrow$


Chatterjee, $\mathrm{P}$.

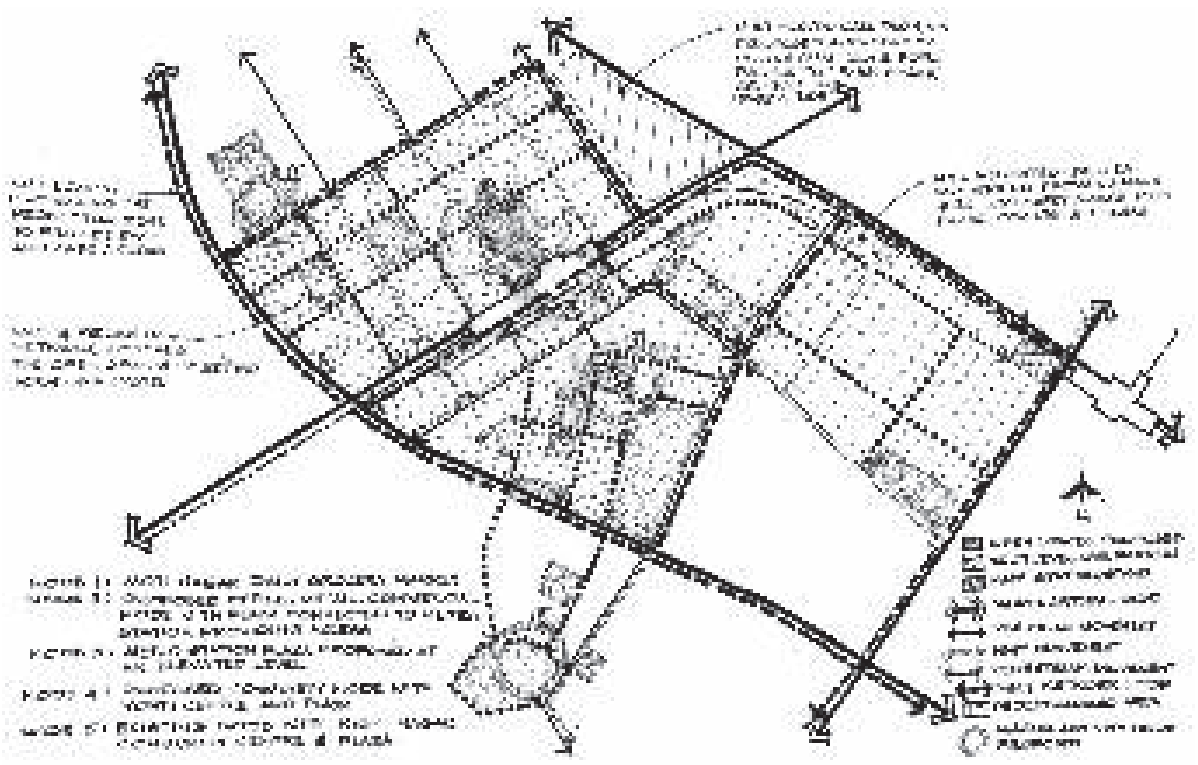

Figure13a: Urban Design Structure Plan deriving Movement Networks, Open Space System (Image source: Author)

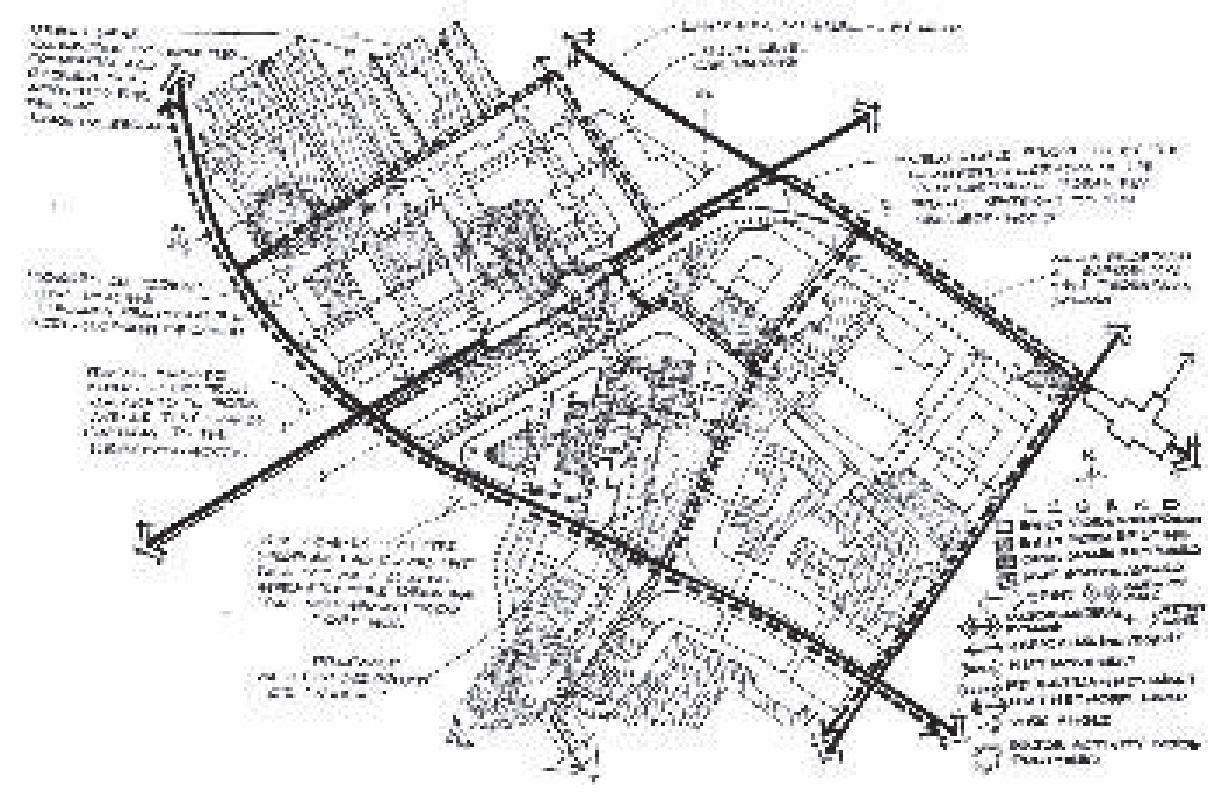

Figure 13b: Urban Design Structure Plan showing the derivation of the Built Form (Image source: Author) 


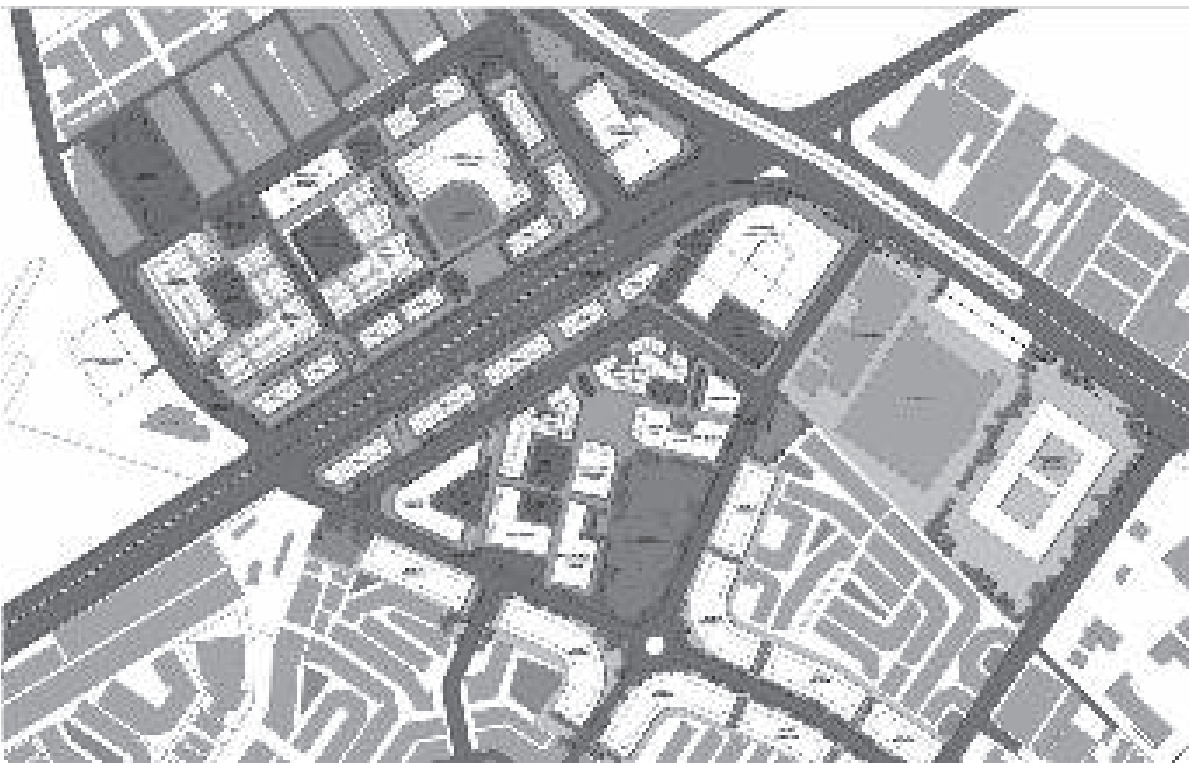

Figure14: Urban Design Master Plan (Image source: Author)

\section{DESIGN DEMONSTRATION: THE NEW NAGARS}

The major spine connecting the Gurudwara in Moti Nagar, running across up to the community centre in Kirti Nagar promises to become the central element in the proposed design of the neighbourhoods. The active foci along the spine, like niches containing informal shops, have to be rendered with urban design details like kiosks, hawker-podiums and sidewalks to compliment to the existing retail edge. The open spaces along schools and temples, are to be outlined with soft vegetative edge instead of the existing hard fenced boundary and opened out to connect with the spine- this will not only activate and revitalize the open spaces but also make them part of the active spine. Open spaces are to be systemized in a hierarchy from as big such as a central multipurpose ground or commercial plaza, to moderately sized parks in between the newly designed building-clusters, till the small tot-lots and courtyards within clusters. Since the roof-tops in the neighbourhoods at present are also connected to the public streets through social interaction they are also to be considered as a third dimensional element in the newly structured open space system.

In the newly designed building blocks, the commercial complex is to be housed in two to three floors from the ground, packed into a podium above
Managing Urban

Transformations of Refugee

Settlements in

West Delhi from

Camps to Nagars:

The Story of Moti

Nagar and Kirti

Nagar

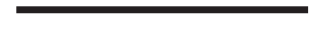


Chatterjee, P.

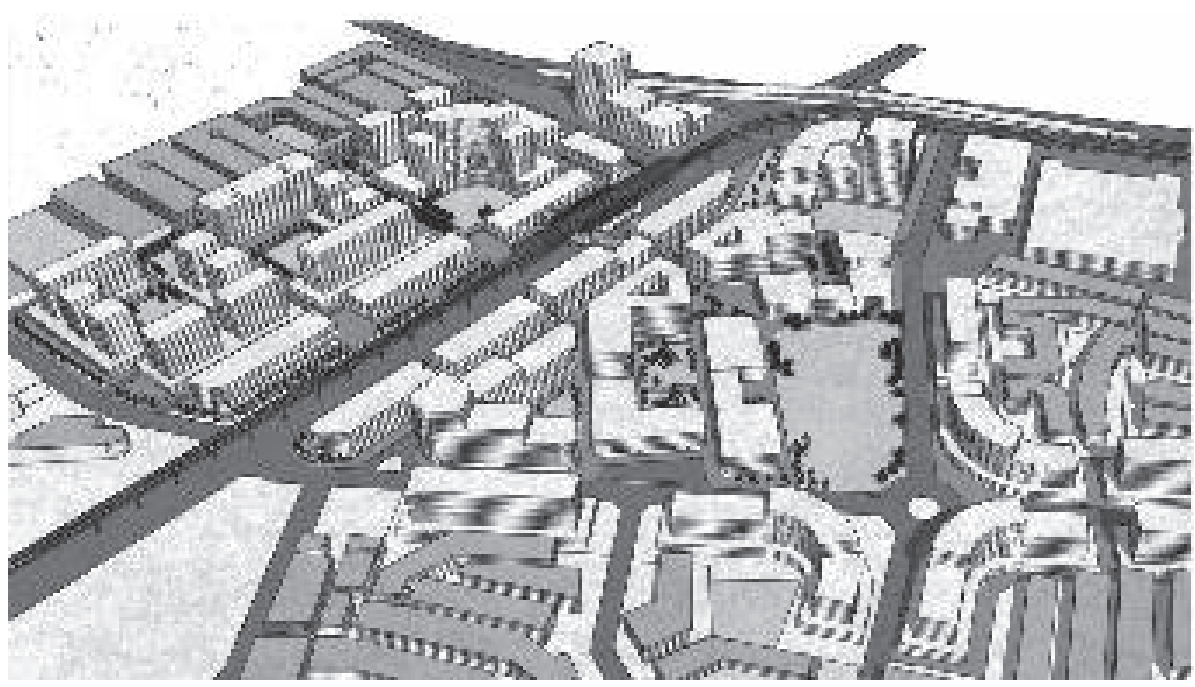

Figure 15: Urban Form derived from design guidelines (Image source: Author)
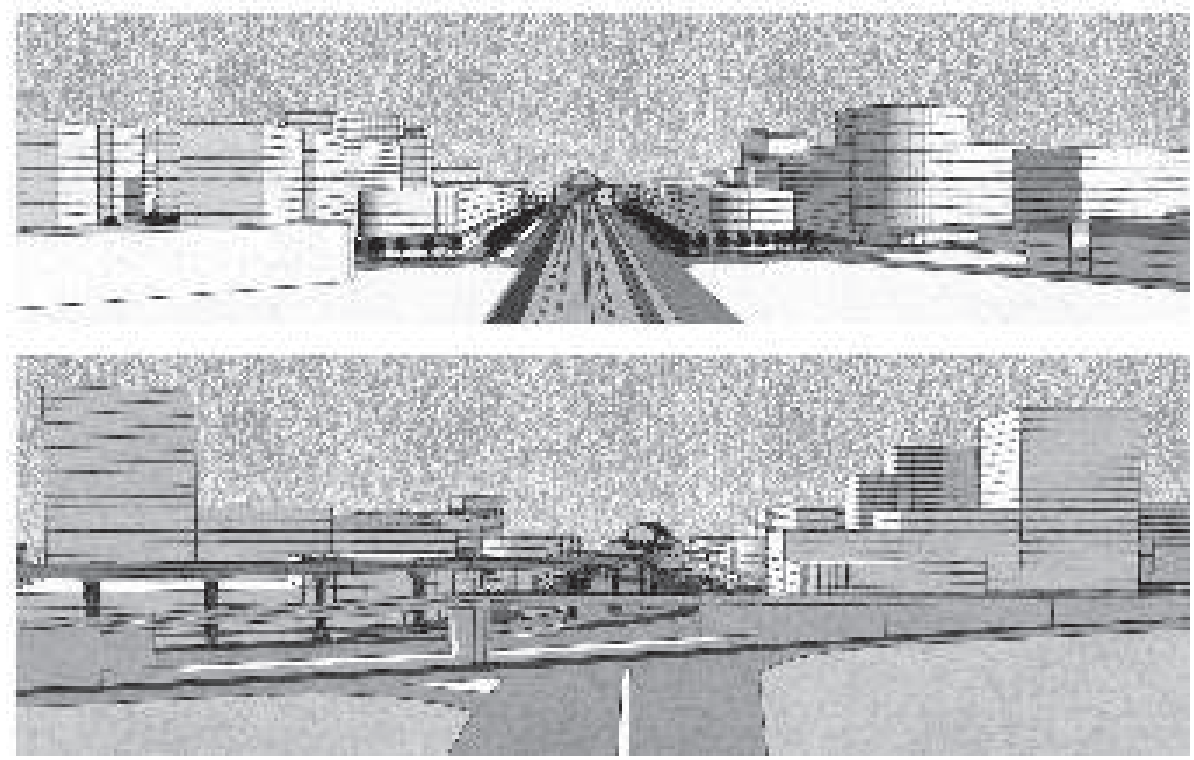

Figure16: Design Sections (Image source: Author) 
which a green roof can be provided for recreation facilities of the residences in the floors above. The retrofitted exhibition galleries would add new flavour to public uses in the neighbourhood whereas the old industrial shed-structures containing them would become imageable as architecturally significant landmarks in the urban fabric holding, in harmony, the old and new patina of time.

The commercial plaza along Moti Nagar Metro Station would appreciably become the central attraction in between the two neighbourhoods (Figs. 14, 15). Being located along a major transit station it will also experience heavy foot-fall and welcome people from other parts of the city. The plaza hence deserves to be detailed out with multiplexes, shopping complexes and offices at the edges and various public activities for active and passive recreation as punctuation within it. This plaza would essentially connect the Nagars from the neighbourhood scale to the city scale by virtue of the various socioeconomic uses and MRTS connectivity it is blessed with (Fig. 16). Thus the functional role of the Twin Nagars, through proper project management and planning, can bring out an efficient urban design scheme, which by communicating and connecting the visions of neighbourhood scale to those of city scale, would appreciably create a suitable identity and sustain the nagars in times to come.

\section{CONCLUSION: INSPIRING THE WAY FORWARD}

Moti Nagar and Kirti Nagar, not only stand out as distinct refugee colonies in the history of Delhi, but are remarkable examples in the history of migrant settlements around the world. Many of these have fallen prey to social conflicts, pressure of market-demands and incompatibilities amongst residing ethnic groups, while others have ended up becoming slums, unplanned areas or even areas unmanageable through planning; but very few have survived. Moti Nagar and Kirti Nagar have survived the test of time gracefully and the aspirations of their residents are still soaring high, holding even higher ambitions for future times.

These aspirations can be fulfilled through urban design and controlled implementation, aided through comprehensive urban management regulating the changes of each phase of transformation. Such an effort would not only connect these people and their settlements with their future dreams but also become a blue-print for a successful planning model for other new upcoming settlements to follow. A Masterplan may derive a vision to cast the light and shun the darkness of future uncertainties, as it has always done; but tying people's ambitions through these principles on real grounds can only be
Managing Urban

Transformations of Refugee

Settlements in

West Delhi from

Camps to Nagars:

The Story of Moti

Nagar and Kirti

Nagar

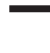


possible by management through urban collaboration programmes laid out in a certain sequence to come up with a holistic urban design that translates aspirations of the commons to the urban form. For Moti Nagar and Kirti Nagar also, the same holds true for fulfilment of future desires through memories of the past. For them too:

\section{'Aspirations build cities and make them live'}

\section{-Christopher Alexander}

\section{REFERENCES}

[1] ADARKAR, N. (2012). The Chawls of Mumbai: Galleries of Life. Gurgaon: ImprintOne

[2] Chatterjee, P., KulkarnI, K., KT, Muthaiah, Hmar. L., Mandal, S.K. (2012). Documentation on the 'Metro City'. Special emphasis on Moti Nagar and Kirti Nagar. New Delhi: School of Planning and Architecture. Unpublished.

[3] Chatterjee, P., Kulkarni, K., KT, Muthaiah, Hmar. L., Mandal, S.K. (2012). Field Survey, Public Meetings and Interviews on site. New Delhi: School of Planning and Architecture. Unpublished.

[4] DATTA, V.N. (2002). Punjabi Refugees and the Urban Development of Greater Delhi. In SPEAR, P., GUPTA, N., FRYKENBERG, R.E. (eds.). The Delhi Omnibus. New Delhi: Oxford University Press.

[5] GLICK, N., Çaglar, A. (2001). Towards a Comparative Theory of Locality in Migration Studies: Migrant Incorporation and City Scale. Journal of Ethnic and Migration Studies. 35(2). p.177-202.

[6] GUHA, R. (2008). India After Gandhi: The History of the World's Largest Democracy. India: Picador.

[7] GUPTA, N. (2011). Picture Focus: Delhi, A City of Refugees. [online]. Available from: http:// blogs.wsj.com/indiarealtime/tag/narayani-gupta/ [Accessed: 15 December 2014]

[8] INDIA. Delhi District Census Handbook: Delhi, Series 27. New Delhi

[9] INDIA. Delhi Master Plan, 1962. New Delhi

[10] INDIA. Delhi Master Plan, 2021. New Delhi

[11] INDIA. MINISTRY OF RELIEF AND REHABILITATION. (1952-53). Annual Report on Evacuation, Relief and Rehabilitation of Refugees. New Delhi.

[12] INDIA. MINISTRY OF RELIEF AND REHABILITATION. (1954-55). Annual Report on Evacuation, Relief and Rehabilitation of Refugees. New Delhi.

[13] JOLLY, U.S. (2010). Challenges for a Megacity. New Delhi: Concept Publishing Company Pvt. Ltd.

[14] KAPADIA, K. (2006) Lost in Transition- A Case of Delhi. In Conference Proceedings of 42nd ISoCaRP Congress. Istanbul, Turkey.

[15] KARANDIKAR, P.N. (2010) Chawls: Analysis of a Middle Class Housing Type in Mumbai, India. A Thesis submitted in partial fulfilment of the Requirements of Department of Architectural Studies, Iowa State University for the degree of Master of Science 
[16] KAUR, R. (2007). Since 1947: Partition Narratives among Punjabi Migrants in Delhi. New Delhi: Oxford University Press. Avaialble from: http://dx.doi.org/10.1093/acprof:o so/9780195683776.001.0001

[17] KAUR, R. (2008). Invisible Delhi. Outlook [online]. Available from: http://www.outlookindia. com/article/Invisible-Delhi/236564. [Accessed: 22 December 2014]

[18] KAUR, R. (2009). Distinctive Citizenship: Refugees, Citizens and Postcolonial State in India's Partition. Journal of Cultural and Social History. 6(4). p.429-446. Available from: http:// dx.doi.org/10.2752/147800409X466272

[19] LAHIRI, N. (2011) Delhi's Capital Century (1911-2011): Understanding the Transformation of the City. In Colloquium Program for Agrarian Studies. Yale University

[20] PRICE, M., BENTON-SHORT, L. (2008). Migrants to the Metropolis: The Rise of Immigrant Gateway Cities. Syracuse: Syracuse University Press

[21] SINGH, K. (2004). City Improbable - Writings on Delhi. Gurgaon: Penguin Books Ltd.
Managing Urban

Transformations of Refugee Settlements in West Delhi from Camps to Nagars: The Story of Moti Nagar and Kirti Nagar 